УДК 343.8

DOI https://doi.org/10.32849/2663-5313/2020.4.47

\title{
Кристина Бабіч,
}

студентка Інституту прокуратури та кримінальної юстииї

Національного юридичного університету імені Ярослава Мудрого

\section{Юлія Мариневич,}

студентка Інституту прокуратури та кримінальної юстииї

Національного юридичного університету імені Ярослава Мудрого

\section{ПОВОДЖЕННЯ ІЗ ЗАСУДЖЕНИМИ, ЯКЕ БУЛО КВАЛІФІКОВАНЕ ЯК КАТУВАННЯ В РІШЕННЯХ ЄСПЛ ПРОТИ УКРАЇНИ}

Стаття присвячена рішенням ЄСПЛ проти України, в яких було констатовано порушення статті 3 Конвениї про захист прав людини і основоположних свобод у контексті поводження із засудженими, яке було кваліфіковане як катування.

Для вивчення питання проаналізовано міжнародні документи, що визначають стандарти з дотримання прав людини у сфері виконання покарань та поводження із засудженими. Дії медичних прачівників щодо засуджених досліджено на відповідність нормам таких загальновизнаних міжнародно-правових документів, як «Приниипи медичної етики, що стосуються ролі працівників охорони здоров'я, особливо лікарів, у захисті ув'язнених чи затриманих осіб від тортур» та «Основні лікарські принципи щодо катувань та інших видів жорстокого, негуманного або принизливого поводження чи покарання при затриманні та ув'язненні» (Токійська деклараиія).

Відповідні положення міжнародних стандартів у сфері поводження із засудженими, а також рішення ЄСПЛ дають підставу констатувати, що наявна проблема дотримання медичними працівниками не тільки приниипів медичної етики, а й загальних міжнародних документів у сфері прав людини.

У статті було проведено порівняння терміна «катування», яке надається в українському законодавстві, міжнародно-правових документах та рішеннях ЕСПЛ. Встановлено, що визначення тер міна «катування», яке надано в Кримінальному кодексі України, відрізняється від визначення, що запропоноване в міжнародно-правових документах.

У роботі сформульована теза щодо необхідності конкретизації суб'єкта в статті 127 Кримінального кодексу України, що дасть змогу значно полегшити кваліфікачію відповідних дій службових осіб, у нашому випадку співробітників адміністрачії виконання покарань. 3 огляду на ие запропоновано внести зміни до Кримінального кодексу України в частині визначення терміна «катування». Під час дослідження також з'ясовано, що Европейський Суд з прав людини не одразу сформулював критерії відмежування «катування» від «нелюдського поводження» та «такого, що принижує гідність поводження або покарання».

Ключові слова: ЄСПЛ, стаття 3 ЄКПЛ, заборона катувань, Конвенція проти катувань, міжнародні стандарти.

Постановка проблеми. Під час ратифікації численних міжнародних договорів Україна взяла на себе зобов'язання, зокрема, щодо захисту прав людини. Водночас проаналізовані рішення дають підстави говорити про проблеми з виконанням узятих зобов'язань, що проявляються в систематичному порушенні прав людини.

Стаття 3 Конвенції охоплює такі елементі, як: катування, нелюдське поводження, таке, що принижує гідність поводження, покарання.

ЄСПЛ також розрізняє відповідні елементи статті і в своїх рішеннях відносить ті чи інші дії до одного з них. Дане дослідження присвячене такій категорії, як катування.
Аналіз останніх досліджень і публікацій. Теоретичним підгрунтям даної статті стали праці таких вчених, як: К. О. Трихліб, П. В. Пушкар, Ю. О. Толстенко, О. В. Лисодєд, А. П. Бущенко, Н. В. Рябих та інші.

Мета цієї статті - дослідження такого елемента статті 3 Конвенції про захист прав людини і основоположних свобод, як катування, в рішеннях ЄСПЛ проти України в в контексті поводження із засудженими.

Виклад основного матеріалу. Для досягнення поставленої мети доцільно проаналізувати термін «катування» в міжнародноправових документах, рішеннях ЄСПЛ 
та Кримінальному кодексі України. Конвенція проти катувань та інших жорстоких, нелюдських або таких, що принижують гідність, видів поводження і покарання містить таке визначення: катування означає будь-яку дію, якою будь-якій особі навмисне заподіюються сильний біль або страждання, фізичне чи моральне, щоб отримати від неї або від третьої особи відомості чи визнання, покарати iiï за дії, які вчинила вона або третя особа чи у вчиненні яких вона підозрюється, а також залякати чи примусити її або третю особу, чи з будь-якої причини, що грунтується на дискримінації будь-якого виду, коли такий біль або страждання заподіюються державними посадовими особами чи іншими особами, які виступають як офіційні, чи з їх підбурювання, чи з їх відома, чи за їхньої мовчазної згоди [1].

«Основні лікарські принципи стосовно тортур та інших видів жорстокого, негуманного або принизливого поводження або покарання при затриманні та ув'язненні» (Токійська декларація) визначає катування як навмисне, систематичне або одноразове заподіяння фізичних чи психічних страждань одним або кількома людьми, що діють самостійно або за чиїмось наказом, з метою змусити іншу людину надати інформацію, зробити визнання або з будь-якими іншими цілями [2, с. 325].

ЄСПЛ не одразу сформував позицію щодо визначення терміна «катування».

Так, у рішенні ЄСПЛ «Ірландія проти Сполученого Королівства» від 1978 року суд оцінив так звані «п'ять методів», якими велися допити, не погодився з висновком Комісії щодо визначення цих «методів» як катування і зазначив, що Суд повинен враховувати відмінність, закріплену в статті 3 , між цим поняттям і поняттям нелюдського або такого, що принижує гідність, поводження. На думку Суду, ця різниця полягає головним чином в інтенсивності завданих страждань. Суд фактично вважає, що Конвенція, з її відмінністю між «тортурами» і «нелюдським або таким, що принижує гідність, поводженням», повинна була до першого з цих термінів надати особливого забарвлення. Також Суд посилався на статтю 1 Резолюції 3452 Генеральної Асамблеї ООН, в якій зазначено: «Катування являють собою обтяжену і навмисну форму жорстоких, нелюдських або таких, що принижують гідність, поводження або покарання» [3].

Виходячи з цього Суд дійшов висновку, що «п'ять методів» не були інтенсивними та особливо жорстокими для того, щоб класифікувати їх як тортури.

У рішенні «Аксой проти Туреччини» від 1996 року йшлося про «палестинське пові- шання», де Суд не тільки повторив думку, що була висловлена в рішенні «Ірландія проти Сполученого Королівства», а й додав, що таке поводження може бути здійснене тільки навмисно, потребує певної підготовки й зусиль. Таке поводження, найімовірніше, було зроблено з метою отримання зізнання або інформації. Суд зазначив, що таке поводження мало настільки серйозний і жорстокий характер, що його можна кваліфікувати тільки як катування [4]. Можна сказати, що дана справа є знаковою в практиці ЄСПЛ, адже термін «катування» набув нових ознак, таких як навмисне, жорстоке поводження.

Міжнародно-правові документи та практика ЄСПЛ загалом дають однакове розуміння терміна «катування».

Натомість Кримінальний кодекс України в ч. 1 ст. 127 дає таке визначення: «Катування, тобто умисне заподіяння сильного фізичного болю або фізичного чи морального страждання шляхом нанесення побоїв, мучення або інших насильницьких дій з метою примусити потерпілого чи іншу особу вчинити дії, що суперечать їхній волі, у тому числі отримати від нього або іншої особи відомості чи визнання, або з метою покарати його чи іншу особу за дії, скоєні ним або іншою особою чи у скоєнні яких він або інша особа підозрюється, а також з метою залякування чи дискримінації його або інших осіб». Дане визначення дещо відрізняється від того, що міститься в Конвенції проти катувань. Вважаємо, що це є недоліком у разі кваліфікації дій співробітників адміністрації за відповідною статтею. Притягнути співробітника адміністрації виконання покарань до відповідальності виключно за статтею 127 неможливо, бо дана стаття не належить до категорії посадових злочинів і не передбачає наявність спеціального суб'єкта [5, с. 60].

ЄСПЛ у рішенні «Каверзін проти України» (п. 178) наголосив на тому, що, незважаючи на загальну законодавчу заборону катування та нелюдського та такого, що принижує гідність, поводження в Україні, на практиці представники державних органів, відповідальні за таке жорстоке поводження, зазвичай уникають покарання. Відсутність щодо цього будь-яких цілеспрямованих зусиль з боку державних органів підтримує обстановку практично повної безкарності за такі дії. М. Ю. Кутєпов наголошує, що «застосування представниками адміністрації насильства до засуджених є істотним недоліком у діяльності та поведінці адміністрації установ виконання покарань. Досить часто передбачені законом заходи стягнення у місцях позбавлення волі замінюються більш простими та зручними для посадовців 
установ виконання покарань. Такими «стягненнями» $є$ застосування фізичної сили, спеціальних засобів, обмеження у забезпеченні побуту, харчування тощо» [6, с. 249].

Не погоджуємося 3 тезою, висловленою П. В. Пушкарем, що загалом надати абсолютно точне юридичне визначення поняття «катування» в кримінальному праві було б неможливо, оскільки це буде в тому числі призводити до проблем із застосуванням цього «негнучкого» визначення на практиці [2, с. 74]. Вважаємо, що внесення змін до статті 127 Кримінального кодексу України в частині конкретизації суб'єкта дасть змогу значно полегшити кваліфікацію відповідних дій службових осіб, у нашому випадку співробітників адміністрації виконання покарань.

Переходячи до аналізу рішень ЄСПЛ проти України за статтею 3 , в яких поводження щодо заявників було кваліфіковано як катування, варто звернути увагу на рішення «Юрій Іларіонович Щокін проти України». Справа стосується сина заявника, якого для відбування покарання було переведено до Вільнянської виправної колонії середнього рівня безпеки, з якої згодом він вчинив втечу. Його було знайдено та доставлено до колонії, де було поміщено в кімнату під наглядом інспектора, який прикував його наручниками до радіатора. Після цього інспектор та семеро засуджених протягом тривалого часу завдавали йому численних ударів, які призвели до множинних травм, переломів та внутрішніх кровотеч. Крім того, двоє засуджених згвалтували його. Наступного дня від отриманих тілесних ушкоджень він помер. Свропейський суд встановив як порушення матеріального та процесуального аспектів статті 2 Конвенції, так і порушення матеріального аспекту статті 3 Конвенції з огляду на катування під час тримання під вартою та процесуального аспекту статті 3 Конвенції з огляду на незабезпечення повного та ефективного розслідування всіх обставин справи.

У справі «Карабет та інші проти України» вісімнадцять заявників стверджували, що зазнали надзвичайно жорсткого поводження під час і після обшуку та операції із забезпечення безпеки, що були проведені в Ізяславській виправній колонії із залученням підрозділів спеціального призначення.

Суд зауважив, що керівництво колонії вдалося до повномасштабних насильницьких дій під приводом загального обшуку та заходів з безпеки, які насправді були спрямовані проти активних організаторів масового голодування засуджених. Згадані протести засуджених обмежувалися мирною відмовою від прийому їжі, та жодного повідомлення про будь-який випадок насильства не було. Відповідні дії адміністрації були проведені після попередньої підготовки із залученням спеціально навченого персоналу.

Кількість залучених до неї службовців перевищувала кількість засуджених більш ніж у три рази. Безпідставне насильство, до якого вдалися державні органи влади, мало на меті придушити рух протесту, покарати засуджених за їхнє мирне голодування та припинити будь-які наміри подати скарги. На думку Суду, поводження, якому були піддані заявники, вочевидь завдало їм сильного болю та страждання. За цих обставин Суд дійшов висновку, що заявники були піддані поводженню, яке можна кваліфікувати лише як катування [7].

Аналізуючи дане рішення, варто звернути увагу на поведінку медичних працівників у даній справі, яка порушує не тільки норми загальновизнаних міжнародно-правових документів, а й таких документів, як «Принципи медичної етики, що стосуються ролі працівників охорони здоров'я, особливо лікарів, у захисті ув'язнених чи затриманих осіб від тортур та інших жорстоких, нелюдських чи таких, що принижують гідність, видів поводження та покарання», прийняті резолюцією 37/194 Генеральної Асамблеї ООН від 18 грудня 1982 року, та «Основні лікарські принципи щодо катувань та інших видів жорстокого, негуманного або принизливого поводження чи покарання при затриманні та ув'язненні» (Токійська декларація, прийнята 29-ю Всесвітньою медичною асамблеєю у 1975 році).

Відповідно до положень, що містяться в Токійській декларації, лікар не повинен надавати жодних умов, інструментів, матеріалів чи знань для здійснення катувань або інших форм жорстокого, негуманного або принизливого поводження, а також для зменшення можливостей жертви чинити опір такому поводженню.

Лікар не повинен бути присутнім при будь-яких діях осіб, що здійснюють катування або інші форми жорстокого, негуманного чи принизливого поводження або погрожують таким поводженням.

Натомість у відповідному рішенні ЄСПЛ зазначено: «Автозак був надто переповнений. Навіть ще до моменту його відправлення багато засуджених втратили свідомість. Медичний працівник приводив їх до тями за допомогою нашатирного спирту» (п. 32); «Інші били його кийками. Від ударів шкіра першого заявника на ногах та сідницях тріскалась. Присутній медичний працівник поливав ці рани водою» (п. 35); «Медичний працівник дав йому 
підписати бланк заяви про відмову від будьяких скарг, що він і зробив» (п. 37) [7].

Відповідно до принципів медичної етики працівники охорони здоров'я, особливо лікарі, чинять порушення медичної етики, якщо вони застосовують свої знання та досвід для сприяння проведенню допиту ув'язнених та затриманих осіб таким чином, що це може негативно вплинути на фізичне чи психічне здоров'я або стан таких ув'язнених чи затриманих осіб та не узгоджується 3 відповідними міжнародними документами, зокрема Загальною декларацією прав людини, Міжнародними пактами про права людини, Декларацією про захист усіх осіб від катувань та інших жорстоких, нелюдських або таких, що принижують гідність, видів поводження та покарання. А також, якщо такі медичні працівники засвідчують чи беруть участь у засвідченні того, що стан здоров'я ув'язнених чи затриманих осіб дозволяє піддавати їх будь-якій формі поводження чи покарання, що може мати негативний вплив на їхнє фізичне чи психічне здоров’я і не узгоджується з відповідними міжнародними документами, або в іншій формі беруть участь у застосуванні будь-якого такого поводження чи покарання [2, с. 541$]$.

У зв'язку з цим досліджено інші рішення ЄСПЛ, в яких було констатовано ненадання належної медичної допомоги. А саме: «Родзевілло проти України», «Герасін проти України», «Єрмоленко проти України», «Гарумов проти України», «Ошурко проти України» та інші.

Проаналізувавши положення міжнародних стандартів у сфері поводження із засудженими і рішень ЄСПЛ, вважаємо, що наявна проблема дотримання медичними працівниками не тільки принципів медичної етики, а й загальних міжнародних документів у сфері прав людини.

\section{Висновки}

У ході дослідження нами було проаналізовано низку рішень ССПЛ, заявниками в яких були засуджені на підставі списку, що надається Міністерством юстиції на офіційному сайті ${ }^{1}$. Зроблено висновок, що в більшості випадків рішення, в яких було констатовано порушення статті 3 , а саме за таким її елементом, як катування, не зустрічаються. У решті рішень, в яких заявниками є засудженні, ССПЛ констатував, що переповненість камер, відсутність свіжого повітря,

1 Рішення щодо України винесені Свропейським Судом $з$ прав людини. Стаття 3 «Заборона катування». https://minjust.gov.ua/m/rishennyaschodo-ukraini-vineseni-evropeyskim-sudom-z-pravlyudini цвіль або бруд у камері, відсутність туалетних засобів, відсутність приватності для туалету, відсутність або обмежений доступ до теплої води, відсутність або погана якість постільної білизни, погана якість харчування, відсутність або обмежений доступ до питної води, відсутність або обмежений доступ до душу, серйозний брак простору у тюремній камері вважається поводженням, що принижує гідність; відсутність комплексного підходу до медичного нагляду, несвоєчасне діагностування працівниками захворювань, ненадання під час тримання під вартою швидкої медичної допомоги становить нелюдське та таке, що принижує гідність, поводження. У підсумку варто зробити акцент на такому твердженні ЄСПЛ, що стаття 3 покладає на державу обв'язок дбати про фізичне благополуччя, осіб, яких позбавлено свободи.

\section{Список використаних джерел:}

1. Конвенція проти катувань та інших жорстоких, нелюдських або таких, що принижують гідність, видів поводження і покарання. URL: https:/ / zakon.rada.gov.ua/laws / show / 995_085 (дата звернення: 03.03.2020).

2. Європейський суд 3 прав людини. Судова практика / за заг. ред. В. Г. Буткевича. Додаток до журналу «Право України». 2011. Вип. 1. Ч. 3 : Стаття 3 ЄКПЛ. Заборона катувань : у 3 ч. 560 с.

3. Ireland v. The United Kingdom : ECHR Judgment, 18 Jan. 1978 // HUDOC. European Court of Human Rights URL: https://hudoc.echr.coe.int/ rus $\#\{\% 22$ tabview\%22:[\%22document $\% 22], \% 22$ it emid\%22:[\%22001-57506\%22]\} (дата звернення: 03.03.2020).

4. Aksoy v. Turkey : ECHR Judgment, 18 Dec. 1996 // HUDOC. European Court of Human Rights URL: https://hudoc.echr.coe.int/ rus\#\{\%22appno\%22:[\%2221987/93\%22],\%22docu mentcollectionid2\%22:[\%22CHAMBER\%22],\%22 itemid\%22:[\%22001-58003\%22]\} (дата звернення: 03.03.2020)

5. Аналітичний звіт за результатами дослідження «Неналежне поводження в діяльності національної поліції України: прояви, поширеність, причини» / Ю. Бєлоусов, O. Бондаренко, В. Оболенцева та ін. URL: https://rm.coe.int/ill-treatment-in-police-researchfinal/16807b4d21 (дата звернення: 13.03.2020).

6. Кутєпов М.Ю. Проблемні питання діяльності установ виконання покарань та їх вплив на виправлення і ресоціалізацію засуджених до позбавлення волі. Юридичний науковий електронний журнал. 2019. № 5. C. 247-250. URL: http://www.lsej.org.ua/5_2019/60.pdf (дата звернення: 04.03.2020)

7. Рішення ЄСПЛ у справі «Каребет та інші проти України» від 17.01.2013 p. URL: https:// zakon.rada.gov.ua/laws/show/974_c69\#Text. (дата звернення: 03.03.2020). 
The article deals with those judgements of the European Court of Human Rights against Ukraine which asserted that there was a violation of article 3 of the Convention for the Protection of Human Rights and Fundamental Freedoms, in the context of the treatment of convicted persons that could be qualified as torture.

In order to explore the matter, specific international instruments were examined, i.e. those used in order to set the standards for the observance of human rights, in the field of the enforcement of penalties and the treatment of convicts. The actions of medical personnel against convicted persons have been investigated in order to determine the degree of compliance with the norms of a number of generally recognized international legal instruments, such as: «Principles of Medical Ethics relevant to the Role of Health Personnel, particularly Physicians, in the Protection of Prisoners and Detainees against Torture» and «Guidelines for Physicians Concerning Torture and other Cruel, Inhuman or Degrading Treatment or Punishment in Relation to Detention and Imprisonment» (Tokyo Declaration). As a result of said examination, it can be argued that there is a problem of medical personnel violating not only medical ethics, but also that of human rights.

The article compares varying definitions of the term «torture» and finds there to be different provision for the term under Ukrainian law as compared to that of international legal instruments and ECHR decisions. The study also found that the European Court of Human Rights did not immediately formulate criteria for the delimitation of torture, cruel, inhuman or degrading treatment and punishment.

It is proposed that the Criminal Code of Ukraine regarding the definition of the term «torture» be amended. The article points to the need to specify the subject in Article 127 of the Criminal Code of Ukraine, which will greatly facilitate qualification of the relevant actions of officials, such as the administrators of the enforcement of sentences.

Key words: ECHR, Article 3rd ECHR, prohibition of torture, European Convention for the Prevention of Torture and Inhuman or Degrading Treatment or Punishment, international standards. 